\title{
Hamsa
}

Journal of Judaic and Islamic Studies

5 | 2019

Muslims and Jews in Latin America

\section{Intracommunity Conflict among New Citizens: Ottoman Immigrants in Late nineteenth century Brazil}

José D. Najar

\section{OpenEdition}

Journals

Electronic version

URL: https://journals.openedition.org/hamsa/357

DOI: 10.4000/hamsa.357

ISSN: 2183-2633

Publisher

CIDEHUS - Centro Interdisciplinar de História Culturas e Sociedades da Universidade de Évora

\section{Electronic reference}

José D. Najar, "Intracommunity Conflict among New Citizens: Ottoman Immigrants in Late nineteenth century Brazil", Hamsa [Online], 5 | 2019, Online since 31 March 2019, connection on 16 September 2021. URL: http://journals.openedition.org/hamsa/357 ; DOI: https://doi.org/10.4000/hamsa.357

This text was automatically generated on 16 September 2021.

\section{(c) (†) $\ominus$}

Hamsa est mise à disposition selon les termes de la Licence Creative Commons Attribution - Pas d'Utilisation Commerciale - Pas de Modification 4.0 International 


\title{
Intracommunity Conflict among New Citizens: Ottoman Immigrants in Late nineteenth century Brazil
}

\author{
José D. Najar
}

1 On December 27, 1898, Mr. Jorge Cure and Mr. Antonio Bachera arrived at the local police station in São Paulo, Brazil ${ }^{1}$, to formally denounce the robbery of 50 fine-tooth combs, 30 scissors, and 20 dozen of switchblades from their business ${ }^{2}$. The businessmen reported the incident in adherence to the law procedures to formally involve the police authorities to recover the stolen merchandise valued at three contos de reis ${ }^{3}$. The men petitioned the authorities "in accordance with Art. 389 of the Brazilian Criminal Procedure Code, to look for and to retrieve the merchandise," which they were told was in position of Mr. Jacob Merchaud, owner of the business Merchaud \& Irmãos ${ }^{4}$. The two men, accompanied by their attorney, signed the obligatory documents in which they swore to the truthfulness of their testimony "without any prejudice," as they were simply "exercising their legal rights.".

2 Mr. Carlos Gonzaga Junior, a scribe at that police station, in accordance to the law and its procedural execution, took the deposition of Mr. Felicio Mizidra to advance the investigation. The testimony of Mr. Mizidra fulfilled one of the multiple legal tasks required by the Brazilian Penal Code. In the police filling, Mr. Gonzaga described Mr. Mizidra as a twenty-five-year-old Arab man. In his deposition, Mr. Mizidra declared that a couple of days before, at nighttime, when the two businessmen were away from their business, "lots of merchandise was stolen". He testified that the stolen property was in the possession of Jacob Merchaud. After the deposition of Mr. Mizidra, the chief of police ordered a search warrant to enter Merchaud \& Irmãos ${ }^{6}$.

Upon his arrival to the business Merchaud \& Irmãos, Mr. Gonzaga read the warrant to Mr. Mercahud, and then proceeded to perform a thorough inspection ${ }^{7}$. He entered the business accompanied by Mr. Severo Rodrigues de Macedo and Mr. Felicio Elias Maziarece, the two witnesses required by law, to perform the search warrant. Mr. Gongaza Junior found three fine-tooth combs, which he confiscated and later delivered 
to the police station ${ }^{8}$. On January 9,1899 , the police chief summoned Mr. Jorge Cure and in the presence of two witnesses, Mr. Moyses Sant'Anna and Mr. Antonio Valenciano, the chief of policed returned the three fine-tooth combs to Mr. Cure. While Mr. Cure and Mr. Bachera did not fully recover their merchandise, one thing was for sure: the Brazilian Penal Code, the police force, and educated citizens worked as a unit to bring order and progress to the Brazilian republic 9 .

4 At the end of the $19^{\text {th }}$ century, as the number of Ottoman immigrants multiplied in the city of São Paulo, intracommunal conflicts often materialized as disputes over commercial affairs in an increasingly competitive labor market. The term Ottoman immigrant(ion) is a corrective to "Syrian emigration", as noted by Kemal H. Karpat, because "the term was once used by outsiders, the emigrants identifying themselves mostly in accordance with religious affiliation or by smaller region, town, village, or tribe...[they] were not all from the territory of Syria...the emigration was not a "Christian" migration either; impelled by many of the same causes that led Ottoman Christians to seek their fortunes in the New World, a substantial number of Ottoman Muslims left their homes and traveled west across the Atlantic ${ }^{10}$." Many Ottoman immigrants upon arrival, chose to peddle. For these immigrants, engaging in the business sector, formally and informally, was an alternative to working in the agricultural and industrial sectors. By the end of the nineteenth century, Ottoman peddlers competed not only against the well-established Italian peddlers, but also against each other ${ }^{11}$. The Cure-Bachera case fits a pattern of commercial crimes increasingly reported to the police authorities during the emergence of the new Brazilian capitalist-free market economy. As a "White" crime, commercial offences involved generally "White" individuals with access to capital, commercial houses, and international trade ${ }^{12}$. However, as an "ethnic" offence, commercial crimes between Ottoman immigrants laid the groundwork for competing images portraying Ottoman immigrants as either dishonest capitalists or hardworking immigrants: the thief turco or the hardworking mascate ${ }^{13}$.

5 Studies about crime in Brazil often underscore the exploding population of the state of São Paulo, as result of state-sponsored European immigration or recently emancipated black population to account for the increase in crime rates in the state ${ }^{14}$. To maintain order, the state sought to modernize structures of state surveillance by reforming the Criminal Code and adopting methods of positivist criminology. As the positivist system of social control organized the protocols to develop an organized system of state surveillance, certain types of criminals were linked to crimes commonly perpetrated by specific groups. Ottoman immigrants became associated with commercial crimes, an offence relative to the type of jobs many performed. The prevention of crime was part of a larger state project aimed to produce law-abiding citizens, but also 'good' workers since theoretically all Brazilians became equal in the eyes of the law after the end of slavery and the proclamation of the Brazilian republic. The gaze of Brazilian institutions, in this context, sought to produce, and reproduce, a type of citizenship based on the republican virtuous positivist slogan: order and progress ${ }^{15}$.

This article examines how the positivist Brazilian republic, through its reformed police, mediated the conflicts and aspirations of individuals and immigrant communities at the end of the 1800 s to develop a modern industrious and orderly society. Fifty-nine police records, collected between 1897 and 1899, provide a glimpse into the reasons for Ottoman inter-community conflict, the powerful role of the positivist state as mediator, 
and the strategies used by Ottoman immigrants to exercise their sense of justice as illustrated in this case study. It posits that as Ottoman immigrants became naturalized Brazilians by Decree no. 58-A of December 14, 1889, termed the 'Great Naturalization' (A Grande Naturalização), they sought the police authorities to settle disputes in order to exercise, their rights as citizens. These were perhaps the very first actions these Ottomans performed as republican citizens, equal to all men in the eyes of the law.

Yet in a country preoccupied with race and color questions, citizenship was informed by the hierarchy of color centered on European whiteness. Brazilian elites, as noted by Jerry Dávila, defined whiteness as "a way of affirming Europeanness, which in turn bore all the trappings of modernity-from urbanization to industrialization, rationalism, science, and civic virtue ${ }^{16}$." Because Ottomans emerged as Whites in Brazil, they had access to economic and social spaces, which even after the end of slavery, continued to exclude non-Whites. Therefore, they needed to protect and invest in the maintenance of their afforded white privileges ${ }^{17}$. Soon, Ottoman immigrants became associated with commercial crimes, an offence associated with Whites in Brazil. Conflict among Ottoman immigrants resulted mainly from socio-economic tensions between two parties with uneven economic status. These interactions involving Ottoman immigrants also contributed to the racialization of a system of laws and practices that from the start ascribed into crimes and criminals, ethnicity, color, and racial markers as it sustained the legacy of the slave state in the newly 'modern' republic through correlations between racial and ethnic categories and crimes.

\section{Ottoman Immigrants and Brazilian Citizenship}

8 The political events of the last decade of the nineteenth century drastically altered the sociopolitical landscape in the state of São Paulo. The republicans' political movement exorcized much of the monarchist political machine, culminating in the foundation of Brazil's First Republic. The political turmoil did little to discourage thousands of immigrants from establishing permanent residence throughout Brazilian territory ${ }^{18}$. Brazil's emerging economy and commercial opportunities filled many immigrants with hope and fueled their desire for economic prosperity. New opportunities developed as the republican government afforded citizenship to many eligible Ottoman immigrants under Decree no. 58-A of December 14, $1889^{19}$. Legally, these Ottoman subjects had begun the process of becoming Brazilians.

9 Much of the historiography on Ottoman immigration to the Americas has emphasized Ottoman government oppression and the massacre of Christians as factors contributing to the exodus of Ottoman subjects from the former Greater Syria province. ${ }^{20}$ However, , as noted by Oswaldo Truzzi, Alexa Naff has demonstrated that much of these arguments "were myths forged, mainly by Arab politicians in the United States, after the end of WWI ${ }^{21}$." it is also important to understand the ways Ottoman subjects utilized the discourses of 'injustice' and 'personal rights' in their new homeland, to construct a sense of shared citizenship and history with their new compatriots. The Ottoman Christian communities in São Paulo found kinship with sectors of the Brazilian population who recently had overthrown the Emperor. For example, the Ottoman immigrant community built the first Maronite church in the city of Campinas on March 3, 189822." After the ceremony laying the first stone, Sheikh El-Kouri addressed the audience in French, speaking of the "persecution Christians suffered in 
Palestine where none of their rights were respected nor they had freedom because of the cruel and barbarous policies of the Sultan ${ }^{23}$." Even where Ottoman Christians belonged to the religious majority, and their integration to Paulista society could be achieved without fear of religious persecution, Christian brotherhood did not necessarily guarantee the absence of social conflicts ${ }^{24}$.

By representing themselves as Christians and with their afforded status as Whites, in Brazil, Ottoman immigrants forged a very distinctive notion of citizenship that differed from their non-White counterparts ${ }^{25}$. This Christian, White form of citizenship supported the ideal of social integration among elites in Latin American. However, this was not simply a strategy for Ottoman immigrants' survival; this was also a technique for social mobility. While all mutual aid and solidarity associations promoted the idea of "rigorously equal human beings ${ }^{26}$," and, in the context of their material culture, in the new land of opportunity, these relations were viable in the "material reproduction of their existences ${ }^{27}$." This understanding of themselves blinded this diverse community from acknowledging their role in the perpetuation of racial inequalities in their new homeland ${ }^{28}$. White and Christian citizenship allowed Ottoman immigrants to make their dreams for a better future a reality at the cost of racial disparity.

Ignacio Klich has noted that during the early years of immigration to Argentina, Ottoman Jews, Christian, and Muslims forged formidable relationships beyond "cordial, good or reasonable ones," by working together in similar fields of economic activities ${ }^{29}$. This follows a pattern of social relations across religious creeds found, prior to immigration, in multi-religious cities in the Ottoman Empire in which "the positive engagement in the affairs of neighbors whose religion was coincidental to their wider urban heritage ${ }^{30}$." At the end of the nineteenth century, the city of São Paulo exuded a sense of "coexistence and great ethnic diversity" ${ }^{31}$ where Ottoman immigrants moved through the city as individuals rather than "collective actors" of one homogeneous community ${ }^{32}$. Historical sources limit any precise consideration of the religious diversity of Ottoman immigrants since "existing data on religious affiliation...are too limited to have a great value in analyzing such a religiously diverse group as the Syrians and the Lebanese $e^{33}$." In this sense, the history of Ottoman immigration to Brazil does not belong to one religious group, even if the majority were Christians. Finally, the government of the First Republic and its body of laws applied equally to all Ottoman immigrants regardless of religious and geographical differences.

As Ottoman immigrants in São Paulo began to carve their place in Brazilian society, community elites embraced the idea of "fazer America," the Brazilian version of the "American Dream." The relative success of the elite Ottoman immigrant businessmen in the growing capitalist market soon collided with the fazer America practice of thousands of other immigrants seeking their own fortunes, among them less-affluent Ottoman immigrants. Sidney Chalhoub points out that "more than half of the 89,000 foreigners economically active worked in commerce, the manufacturing industry and artistic activities; the immigrant population occupied the more dynamic areas of employment $^{34}$." The disputes between peddlers and their merchandise dealers, within a framework of class and labor conflict, emerged as processes intended to influence community peddlers' work ethic, while simultaneously mapping socioeconomic relationships mirroring employee-employer ones. In this context, well-established community members were not only models of success, they were also agents of discipline. If notions of respectability, masculinity, and honesty were to be found only 
among those employed as salaried workers in the emerging Brazilian capitalist job market, what were the alternatives for the Ottoman immigrants whose employment practices separated them from salaried work? Where did they fit within the new labor system that categorized individuals as good workers or loafers?

\section{Creating White Color Crimes} adjustments to a group's internal tensions ${ }^{35}$. Others have explored the ways conflict in the form of criminal activities, regardless of their violent nature, evolved as medicalcriminal conditions rather than moral transgressions. Interestingly, the medicalization of criminal activities and the "making of the criminal" became diametrically opposed to the liberal ideals of democratic individual responsibilities. In Brazil, the medicallegal discourse emerged as a byproduct of the new criminal code and positivist criminal practices that removed the sense of accountability from the individual engaged in criminal behaviors by reducing their actions to inherent biological predispositions ${ }^{36}$.

Concurrently, scholars have contextualized such routine conflicts within Brazil's new capitalist economic project. Conflict among native Brazilians and immigrant groups developed through racialized immigration laws favoring White European immigration and the marginalization of the black worker ${ }^{37}$. Under the republican government, positivist laws and codes regulated the working practices of those involved in smallscale commerce, arbitrated by the courts and the police authorities. The new professional police administrators served as brokers between the conflicting parties seeking "justice" from the authorities. Additionally, police administrators, in accordance with the new penal code and constitution, kept not only detailed information regarding the grievances of the accusatory party in the form of police depositions, but also biometric data to identify positively the individuals involved. The identification process, rooted in the sciences of anthropometrics and mediated by the police, deliberately associated Ottoman and other White immigrants with commercial "crimes" (Table 1).

This is not surprising since White natives and immigrants often monopolized the commercial sectors of Paulista society ${ }^{38}$. In his study on crime in São Paulo, Boris Fausto characterizes the 'Arab' population as White (Table 1). The documents Fausto scrutinized labeled Arabs as White, as did most documents produced by the state. This is in line with understandings about Ottoman immigrants in Brazil, especially those from the former Syrian Province. According to earliest Brazilian eugenicists such as Raimundo Nina Rodrigues ${ }^{39}$, an advocate against racial miscegenation because of the possible degradation of the Brazilian race, 'Arabs' were both White and civilized ${ }^{40}$. However, in the process of producing police records, which described the details of both the incident and the parties involved, the centrality racial making enterprise rested on the figure of the police scribe.

In his study on crime in São Paulo, Boris Fausto characterizes the 'Arab' population as White (Table 1). The documents Fausto scrutinized labeled Arabs as White, as did most documents produced by the state. This is in line with understandings about Ottoman immigrants in Brazil, especially those from the former Syrian Province. 
Table 1.

Indicted for receiving and selling stolen goods (Fencing/Receptação) 1880-1924

\begin{tabular}{|c|c|c|c|c|}
\hline Nationality & Color & Sex & Education & Criminal record \\
\hline Italian 30 & White 71 & Men 69 & Read \& write 49 & Negative 21 \\
\hline Arabic 13 & Black 1 & Women 6 & Illiterate 18 & Positive 5 \\
\hline Brazilian 10 & Mulato 1 & & Unspecified 8 & Unspecified 49 \\
\hline Portuguese 8 & Unspecified 2 & & & \\
\hline Spanish 6 & & & & \\
\hline Others 3 & & & & \\
\hline Unspecified 5 & & & & \\
\hline Total 75 & & & & \\
\hline
\end{tabular}

Source: B. Fausto, Crime e cotidiano, p. 13941.

17 In Brazil, scribes dedicated their professional lives to collecting, authenticating, and organizing the mundane actions of everyday people and state procedures. The documents they produced contain countless instances of interactions between plaintiffs, defendants, and the state. During the last three years of the nineteenth century, the police of the city of São Paulo incarcerated at least fifty-five Ottoman immigrants: fourteen identified as Turkish ${ }^{42}$, thirty-nine as Syrians and one as Greek ${ }^{43}$. The majority were detained at the request of a business associate or lender because many failed to pay a loan. Elias Abrão Chaes was imprisoned at the request of Abrão Abadalla Atyé for failing to pay a loan of 41:000 contos de reis ${ }^{44}$. Felicio José was released after paying his debt of 20,000:00 contos de reis to his lender Miguel João ${ }^{45}$. José Massude failed to pay 1,792:370 contos de reis he borrowed in merchandise to Bargio Malta Hespanhia ${ }^{46}$. Salim Tauf Maluf asked for the detention of his employees (peddlers) José Massude and Amim Tave because both men failed to pay their loan and tried to run away ${ }^{47}$. In general, these records provide names and dates of individuals directly involved in civil or criminal investigations and litigations. They also reveal personal information about individuals indirectly implicated in police proceedings, usually summoned by the authorities to collaborate or to produce testimonies as eyewitnesses. For historians interested in the everyday lives of immigrants to Brazil, these records are often the only sources in which the lives of thousands of immigrants became part of the historical records in the host country.

Historians working with legal documents have highlighted the special relationship between the public or private scribe and the social construction of "truth." In accordance with their public duties, scribes acted as witnesses of all police proceedings, from dramatic cases to the most mundane: from the assassination of a political figure, to the theft of a peddling box. The scribe structured the depositions of the parties involved, shaping a coherent narrative of past events by considering the multiple facts and important details brought to police headquarters. The testimonies often followed a predetermined structure informed by the requirements of the law. This modality used specific language dictated by "manuals with specific itineraries of meaning ${ }^{48}$." As noted by Katherine Burns, legal manuals used by scribes, "in Europe and the colonial Americas to guide these men in straitening the endless diversity of people's actions and language into the approval formulae ${ }^{49}$." The ability of police scribes to follow established formulas produced hybrid narratives that converted unique social disputes 
into formulaic arrangements. In this sense, police scribes, "were thus truth's alchemists, mixing the singular into the formulaic in accordance with the prescribed recipes to produce the written, duly witnessed, and certified truth. Their truth was recognizable not by its singularity but by its very regularity. It was truth by template la verdad hecha de molde $e^{50}$." Indeed it was the regularity of Ottoman immigrants involved in commercial disputes that both associated them with commercial transgressions and found them regularly exercising their rights as citizens. Here, the paradox of the thief 'Turco' and the good peddler emerged through the interactions of the community itself, molded by the reality of daily occurrences.

Thus, police records often obscured important details about the everyday life of the people and events captured in their reports. This is in part because of the very "template" nature of these records, which structured and filtered conflict and resolution narratives through the lenses professionalized standards. Such is the case of Merad Selman, an Arab peddler, who sought the help of the police authorities to retrieve his peddling box in possession by Mr. Felio Najar ${ }^{51}$. According to Selman's initial deposition, in his absence, Najar broke into his home and took the "peddling box containing various objects and stored it in a house located on 25 de Março Street ${ }^{52}$." Selman repeatedly asked for the peddling box, but Najar refused unless Selman paid one conto de reis he owed him ${ }^{53}$. Thee 'Arab' witnesses, José Antonio, Najib Kuri, and Alexandre Najib, testified that Najar, afraid that Selman would not pay back his loan, decided to retrieve the peddling box himself ${ }^{54}$. Since the depositions presented by the parties involved, as well as by witnesses of the case, were the most important evidence in convicting or absolving the defendant, police scribes assumed the role of interlocutor between the realms of speech and writing ${ }^{55}$. On July 13, 1898, at the Santa Ephigena Police Station in São Paulo, Paulo Antonio, a 'Syrian' businessman, accused his employees, Jacobo Caram and Miguel Khamil, of stealing manufactured clothing (roupas feitas), from his place of business. Five 'Syrian' witnesses were summoned. Antonio Miguel, Miguel Paulo, José Elias, José Miguel and Felicio Antonio, the last two with the assistance of Mr. Fares Simão Najib, an appointed Arabic translator, collaborated the accusations and guilt of the two defendants presented by the plaintiff ${ }^{56}$.

The documents produced by police scribes are unique in that they must "register the established communicative situation, simultaneous with the act of writing, between the police authority and the deponent, as reliably as possible ${ }^{57}$." The liminal space ${ }^{58}$ from which police scribes produced these written police records contained "forces and grids of meaning that shaped such records ${ }^{59}$." In other words, the 'reliability' of these texts is limited by the negotiations that take place between the scribal template and the traces of "understandings that often belie the wording of the text ${ }^{60}$ ", police records illustrate the importance of police stations in which professionalized men produced as part of their occupational duties "documents we now rely on to make our own sense of the past." Ottoman immigrants and natives sought the help of the police to exercise their rights as citizens, from time to time mediated by language translators, at a transitional historical moment of high state intervention, which sought to create order and progress through different state apparatus in order to discipline its modern citizens. 


\section{Negotiating Truth}

21 On February 14, 1898, Eisa Aubud made his way to Police Station Number Four, in the capital city of São Paulo, to file a complaint against Abdul Falá. According to the testimony of Mr. Aubud, Mr. Falá came to his establishment on February 10, to buy 5,600 meters of silk ribbon and asked the plaintiff "to take the merchandise to his house located at 63 Dr. Gusmão Street ${ }^{61}$." The merchandise was delivered to the location requested and left in the possession of Falá. For some unexplained reason Mr.Falá reconsidered the transaction and "refused to either pay for the merchandise or return it to the plaintiff ${ }^{62}$." In his complaint, Mr. Aubud asked the authorities to expedite the process and ordered the defendant to return the silk ribbon. The deputy of police, Dr. João de Deus Sampaio, formally swore-in Mr. Aubud in the presence of his scribe, Antonio Pereira Pinto Machado ${ }^{63}$. This case illustrates the legal procedures executed to retrieve the merchandise in possession Mr. Falá. To substantiate the 'truthfulness' of the plaintiff's claims, and in accordance with the law, Dr. Sampaio summoned three eyewitnesses to his office, Felippe Orfilim, Felippe Pedro, and Miguel Curi, all Ottoman immigrants. As part of the legal proceedings, witnesses had to declare under oath that they had no relationship to the defendant. The fact that all three witnesses were members of the small Ottoman immigrant community of São Paulo added complexity to the legal proceedings. To suggest that the eyewitnesses involved in this case had no legal or personal relationship to the plaintiff undermines the close sociocultural relationships among these Arabic-speaking Ottoman immigrants. To uncritically question intracommunity relations, in addition, undermines the economic or material relationships among the five individuals involved in this case: the witnesses, the defendant, and the plaintiff. As will become clear, all three witnessesbecause of the nature of the job-relied on individuals such as Mr. Aubud, a wellstablished merchant, to make a living. Their involvement in this legal case provided them with greater cultural and social capital that, in turn, could potentially increase the likelihood of their expanding or eventually acquiring their own businesses. By subjecting themselves to Mr. Aubud's sphere of influence, these witnesses were hoping to achieve social mobility ${ }^{64}$. The testimonies are relatively short, standardized, and to the point. They illustrate the necessary steps the police force took to retrieve the silk ribbon and return it Mr. Aubud. The structure of each of the recorded testimonies followed a technical format with little room for divergence.

\section{First Testimony}

Felippe Orfilim, an Arab peddler, offered his testimony under oath and in accordance with the customary practices of the law. Orfilim declared that Mr. Abdul Falá had come to see Mr. Aisa Aubud to purchase 5,600 meters of silk ribbon. After the transaction, Mr. Falá asked Mr. Aubud to deliver his purchase to his home address, which he did. Now, the defendant Mr. Falá refused to either pay or return the ribbon ${ }^{65}$. The testimony was read back to Mr. Orfilim in accordance with the law. Since he did not know how to write, Antonio Pereira Pinto Machado, the scribe, signed for him as a way to accept that what he had recorded was Orfilim's "true" testimony. 


\section{Second Testimony} that Mr. Abdul Falá had come into the business of Mr. Aubud to purchase 5,600 meters of silk ribbon. After the transaction, Mr. Falá asked Mr. Aubud to deliver his purchase to his home, which Mr. Aubud did "in good faith ${ }^{66 "}$.

\section{Third Testimony}

Miguel Curi, an Arab merchant, gave the third and last testimony. He testified that on that day, he saw Mr. Falá coming in to the business of Mr. Aubud to buy 5,6000 meters of silk ribbon and asked the plaintiff to deliver it to his house. Now, the defendant no longer wants the ribbon, refuses to make the appropriate payment, and refuses to return it to the rightful owner, the plaintiff ${ }^{67}$.

These depositions corroborate a certain highly-structured version of what transpired in Aubud's place of business. The police scribe took the witnesses' depositions and inserted the presumed facts into a standard police testimony form. The three testimonies were strikingly similar, in that all three, aside from the personal information provided by each witness, describe the sequence of events and facts in the same way-from the arrival of Falá at Aubud's business to Fala's unwillingness to pay for or return the merchandise. In this case, the scribe chose to redact the testimonies of the three men so that a particular version of the truth could be pursued.

Yet, a closer look at the testimonies of this case reveals two major fallacies-one legal, the other temporal. The former relates to the phrase "aos costumes disse nada $a^{68}$," which, in legal terms, suggested that the witnesses had no relationship to the defendant. This is inaccurate, first, because all three witnesses were members of a small, interconnected ethnic community that likely shared religious and or geographical origins. Second, a commercial relationship existed between the three men and the plaintiff. This point is important to highlight because commercial relationships between Ottoman immigrants involved in the informal market of trade and exchange, in late nineteenth century São Paulo, relied heavily on friendship, honesty, and good reputation. These factors greatly contributed to the peddlers' and small merchants' acquisition of merchandise from larger commercial houses. These economic relationships, based upon ethnic and religious alliances, made it possible for merchants and peddlers to borrow large amounts of goods in good faith with the promise of repayment once they sold the merchandise. In some instances, years went by before repayment ${ }^{69}$. Although many peddlers and small merchants depended on their own self-employment practices, they did come to rely upon the business relationships they forged with the owners of the supplying businesses.

The fact that the police scribe failed to either interrogate or acknowledge the nature of the relationship between the plaintiff and the witnesses might be explained by considering the historical division of labor between masters and servants in Brazilian society. If the wage labor system replaced the system of slavery, in which slave owners became the new bosses and slaves the new workers within the new facenda/factory reality, then individuals working independently fell out of reach of these labor relationships. Peddling, legalized during the Empire period, was historically one of the many tasks in the world of slave labor in Brazil ${ }^{70}$. This narrow understanding of the 
emerging capitalist economic system and the ways in which it influenced social and labor relationships-especially among different social classes within any given ethnic enclave-shows that the testimonies of the three men failed to account for these relationships of power and in so doing, privileged the most affluent of the disputing parties. In addition, the logic of police inquisitorial practices did not afford the defendant the right to summon character witnesses in his defense. This led to an investigation which, from the start, favored the plaintiff. As result, the unevenness of these reports obscures the relationships between Mr.Fala and other members of the community, potentially including the witnesses for the defense.

A second and problematic characteristic of the testimonies is the sequence of events provided by all three witnesses. According to the three men, Mr. Falá came into Mr. Aubud's establishment to purchase 5,600 meters of silk ribbon, and then refused to pay for or return the merchandise. While Falá came into the establishment and agreed to purchase the ribbon, it is improbable that all three men witnessed Mr. Falá's refusal to pay for or return the ribbon. This observation speaks to the ways in which the police scribe negotiated the facts of the event and produced a hybrid narration of his own understanding of what had occurred in the case. It is noted in the testimonies that Mr. Falá asked Mr. Aubud to deliver the merchandise to his home address. The testimonies also demonstrate that there was some kind of previous relationship between the two men since Mr. Aubud delivered the merchandise without payment from the defendant and left the merchandise in "good faith" in the possession of Mr. Falá. The three witnesses could not possibly have known the outcome of the transaction between Aubud and Falá, unless all four men had delivered the merchandise together. This point illustrates how the police scribe interpreted the facts to produce a coherent timeline of the events.

Scholars have explained these seemly inaccurate testimonies through constructivist theories which highlight the false-recognition effect that people experience during certain events. For them, memories "become integrated with inferences and other elaborations that go beyond the direct experience. Recognition, as well as recall, is said to be based on integrated semantic representation in which memory for experiences is intertwined with its interpretation ${ }^{71}$." Yet, to adhere to such explanations suggests that disingenuous information may account for the inability of the individual to efficiently store the remembrances of any given event. This is problematic because of the time that elapsed between the actual event and the time of the deposition: four days. For scholars Valerie F. Reyna and Allison L. Titcomb, an alternative approach to constructivism is that of misattribution, "in which memory distortions are analyzed as a source of errors. Suggestibility effects could occur because witnesses confuse the contexts in which they received original information with those in which they received misinformation [...] In this case, witnesses might retain accurate memories of both experiences that are not integrated with one another, contrary to constructivism ${ }^{72}$." In this sense, it is probable that the recap of events by the three witnesses constitutes a version of reality, based on their recollection of the facts, organized around the information acquired in Mr. Aubud's business, possibly during different times, and constituted as real and honest information. Thus, the memories of the actual event are associated with the understanding of that particular experience ${ }^{73}$. Regardless of the succession of the events, the scribe figuratively and literally had the last word. 
In this light, a third alternative suggests that, after several days, Mr. Aubud grew tired of waiting for either payment or the return of his merchandise. In this situation, Mr. Aubud positioned himself in the role of a victim, or what Sidney Chalhoub calls a "futile aggression," and in so doing, Mr. Aubud justified his actions ${ }^{74}$. He began to tell his business associates that Mr. Falá was refusing to pay or return his merchandise. This inflammatory assumption might have upset Mr. Falá, who, as a merchant, relied on his reputation as a trustworthy person, a good worker and good citizen, to acquire merchandise for his business. The tarnishing of his reputation may have angered $\mathrm{Mr}$. Falá to the point that he then refused to pay for the merchandise and kept it as payment or punishment for the offense. Additionally, the simple act of making this 'private' (among community members) matter public by involving the police, could have further irritated Mr. Falá, since this action undermined 'traditional' forms of settling intracommunity disputes; yet effective in the new reality of liberal rights in republican Brazil. The way Mr. Falá reacted constituted an informal approach to this situation. If, indeed, Mr. Aubud had damaged some aspect of their relationship, then Falá should have sought the mediation of the law. However, the law could not return his sense of honor, good worker, or good citizen. Then law could only return what it constituted stolen merchandise to its rightful owner.

Based on the testimonies, the police deputy, Dr. Sampaio, issued a warrant to retrieve the merchandise from Mr. Falá's house. He directed the police station's scribe to proceed with the "most rigorous search in order to comply with the above order ${ }^{75}$." If necessary, the scribe was authorized to "open any doors in the house, cabinets, and drawers, exercising all indispensable diligences in order to make the apprehension of the silk ribbons ${ }^{76}$." After presenting the warrant to Mr. Falá, in the company of two witnesses, José Duarte de Silva and Arthur Pinheiro Guimarães, Mr. Pinto Machado proceeded to do the "most thorough search, examining all halls and rooms, and locked places (opening all locked doors) and finally, when he walked into a room facing the street, he found the 5,600 meters of ribbon, which he then took under his possession." 77 Here the police scribe becomes personally and professionally involved in the case. , In his role as agent of the state, the police scribe has now not only negotiated onto paper the different oral testimonies from the parties involved, but also become a witness himself, which complicates faithful reconstruction of events under his review. After retrieving the silk ribbon, Mr. Pinto Machado took the merchandise back to the police station where the police deputy summoned the public custodian to take charge of the confiscated merchandise. The police deputy did not automatically return the merchandise to Mr. Aubud because Falá, through his attorney, José Riskallha, pled with authorities to deposit the merchandise in the hands of the public custodian. Mr. Falá made this request because he believed that Mr. Aubud was "not trustworthy ${ }^{78}$." Mr. Aubud quickly used his sense of citizenship and personal rights to retaliate against Mr. Falá. Through his attorney, Mr. Aubud stated that:

"Mr. Eisa Aubud, in defense of his rights, [asked the authorities] not to proceed with the process filed by Abdul Falá, since this warrant for search and apprehension, issued by the police, had the intention of returning the respective apprehended objects to the plaintiff, who is their legitimate owner, which has been fully proven in this police station...

Regardless, the plaintiff is an honest man (homme honesto), trustworthy, owner of a fortune in consumer goods, and the defendant, Mr. Abdul Falá, has not proven anything 
in this police station. And, if this man, for some reason, believes [himself] to be a creditor of the plaintiff and wants [to] make a rightful claim to the referred deposited merchandise, he should make a seize and embargo appeal, but has he done so? Under these conditions, I attach this [complaint] for the appropriate jury ${ }^{79}$."

The statement above suggests that Mr. Falá kept the merchandise obtained from Mr. Aubud as a means of collecting compensation from the plaintiff. What happened between these two men after the delivery of the merchandise and prior to the filing of the police complaint? By invoking Mr. Falá as a bogus creditor, Mr. Aubud acknowledges the grievances-although, in his perspective, unfounded-surrounding the conflict. In questioning the inability or unwillingness of Mr. Fala to pursue the legal channels necessary to justify his actions, Mr. Aubud not only challenges the legality and reality of Mr. Falá's complaint but also suggests that whatever the nature of Mr. Falá's counter-complaint, it cannot be proven by material evidence. In other words, Mr. Aubud had not stolen or kept any property belonging to Mr. Falá, and, therefore, Mr. Falá cannot prove his countersuit in the eyes of the law. To dismiss fully the counterclaim against him, Mr. Aubud uses his good character, social standing, along with his economic assets, to vindicate his case. Mr. Aubud exercises his good worker and citizen rights against Mr. Falá. This is not a new strategy in a capitalist society. Mr. Aubud understands that his gender and class status, along with his claim to an honest character, may successfully place the law on his side. Although the police process ends here, the dispute between the two men was far from over. It is likely that this process was later tried by the courts, yet the result of the proceedings is unknown.

This case suggests that Ottoman immigrants sought the intervention of the state as an alternative or additional mediator of intracommunity conflict ${ }^{80}$. They used the police and other governmental bodies to settle their disputes. This example serves to complicate further the interrelationships within the Ottoman immigrant community. Oswaldo Truzzi understood the complexity of these relationships, as he pointed out that " $[t]$ hese relationships manifested themselves in an infinite number of mechanisms which have evolved since the reception of the newly arrived by those already living here to the apex of the complementary relationships established between industrialists and great businessmen ${ }^{81}$." While Truzzi sees conflict resolution within the boundaries of the community itself, state intervention bridged the communal and the public.

Finally, Truzzi also warns about the limits of the multiple types of relationships within the community. He noted that "[... T] The Syrians and Lebanese favor individual autonomy, the opening of their own business-ultimately, one who does well today, often has the potential to become a competitor tomorrow. The translation of this implicit limit in the sphere of kinship relationships coined an admirable proverb in the community: 'Every Lebanese is everyone's cousin until his first bankruptcy ${ }^{82}$."' This reveals the volatile economic relationships among community members. It also illustrates the challenges of cooperation and family-like dynamics in light of economic failure or the transgression of a business relationship. However, conflicts litigated in police stations generally involved community members who had lived in Brazil long enough to efficiently use their wealth to pay all fees associated with the litigation and citizenship status. For community members in better economic positions, their economic independence freed them from the more constrained interpersonal relationships experienced by those newly arrived in São Paulo. In the context of upward social mobility, newly arrived country men often turned into "competitors ${ }^{83}$." 
It is impossible to assess in this study the negative consequences of the loss of economic mobility and livelihood among those who failed to repay their debts. At best, these 'White-crime' criminals positively modified their work ethic, followed the law as model citizens, and eventually achieved economic success. At worst, they ended their lives as tragic characters in a novel: poor and far away from their homeland ${ }^{84}$.

\section{Conclusion}

Because most Levantine immigrants engaged in commerce as peddlers, shopkeepers, and merchandise dealers, Ottoman immigrants did not fit the new positivist model of a "good worker," an ideal often liked to salary workers. Instead, working relationships between community members were enmeshed with commercial disputes centered on class conflict, and mediated in the courtrooms and police stations. The fact that the Ottoman immigrants sought the aid of the authorities to settle commercial disputes projected a social image of good citizenship that is orderly conduct and civil obedience to Brazilian laws.

In accordance newly positivist laws and procedures, police officials investigated these disputes by reviewing the evidence provided to them in the form of depositions by plaintiffs, defendants, and witnesses. It was the duty of the police scribe to redact carefully the facts of the case and to produce police proceedings adhering to professional and legal standards. Some of these duties included the racial, ethnic, and color classification of those individuals under the authority of the police force. These documents are the closest one can come to experiencing the lives of Ottoman immigrants during the earliest moments of their arrival to their host country in the late nineteenth century. At the end, disputes among Ottoman immigrants captured by police scribes, illustrate these new citizens exercising their new afforded rights, jointly learning together, how to become Brazilian citizens.

\section{BIBLIOGRAPHY}

\section{Archival sources:}

Arquivo do Estado de São Paulo, Acervo Permanente-Processos Policiais (AESP, AP, PP), Jorge Cure, Antonio Bachera, 1-3, 6, 9 e 12; Justiça Polícia (JP), n. 3 (7/8/1897), n. 6 (7/18/1897), n. 12 (7/27/1897), n. 16 (8/3/1897), n. 34 (9/3/1897), n. 35 (9/5/1897), n. 37 (9/8/1897), n. 45 (9/11/1897), n. 46 (9/12/1897), n. $94(11 / 5 / 1897)$, n. $99(11 / 13 / 1897)$, n. 114 (12/5/1897), n. 115 (12/5/1897), n. 120 (12/16/1897), n. 121 (12/15/1897), n. 122 (12/19/1897), n. $129(12 / 30 / 1897)$, n. $162(1 / 8 / 1898)$, n. $252(6 / 2 / 1898)$, n. 258 (6/8/1898), n. 262 (6/13/1898), n. $263(10 / 21 / 1898)$, n. 268-A (6/26/1898), n. 269 (6/26/1898), n. 298 (8/1/1898), n. 353 (9/26/1898), n. 358 (7/15/1898), n. 359 (10/12/1898), n. 385 (11/21/1898), n. 407 (12/12/1898), n. 408 (12/19/1898), n. 415 (12/29/1898), n. 453 (2/17/1899), n. 462 (2/26/1899), n. 470 (3/5/1899), n. 483 (3/10/1898), n. 522 
(4/22/1899), n. 527, Jose Abrão Cater, n. 528 (4/28/1899), n. 537 (4/28/1899), n. 563 (5/10/1899), Alexander Gabriel Lafeicher, n. 564 (5/10/1899), n. 612 (7/6/1899), Pedro Nahme, n. 635 (7/23/1899), n. 670 (9/30/1899), n. 695 (S/D). Greek: AESP/JP, E01616, n. 127 (12/23/1897).

\section{Bibliography:}

AGUIRRE, Carlos, BUFFINGTON, Robert, eds., Reconstructing Criminality in Latin America, Wilmington, Scholarly Resources, 2000.

ALMEIDA, Renata Geraissati Castro de, "Trajetória de um patrício - A imigração sírio libanesa em São Paulo", Revista Outras Fronteiras 1.2 (2014), pp. 302-322.

ANDREWS, George Reid, Blacks and Whites in São Paulo 1888-1988, Madison, University of Wisconsin Press, 1991.

BEAUGRANDE, Robert de, DRESSLER, Wolfgang U., Introduction to Text Linguistics, London, Longman, 1981.

BECKER, Peter, WETZELL, Richard F., eds., Criminals and their Scientists, Cambridge, Cambridge University Press, 2006.

BENTO, Maria Aparecida Silva, "Branqueamento e branquitude no Brasil", in Psicologia social do racismo - estudos sobre branquitude e branqueamento no Brasil, orgs. Iray Carone e Maria Aparecida Silva Bento, Petrópolis, RJ, Editora Vozes, 2002, pp. 25-58.

“Brazil: New Naturalization Law", Bulletin of the Pan American Union 14 (1903), p. 386.

BROWN, Gillian, “Understanding Spoken Language”, TOSOL Quarterly 12.3 (Sep. 1978), pp. 271-283.

BURNS, Kathryn, "Between the Lines", in Of Things of the Indies: Essays Old and New in Early Latin American History, Stanford, Stanford University Press, 1999, pp. 229-80.

BURNS, Kathryn, “Notaries, Truth, and Consequences", American Historical Review, 110.2 (2005), pp. 350-379, https://doi.org/10.1086/ahr/110.2.350.

CHALHOUB, Sidney, Trabalho, lar e botequim: o cotidiano dos trabalhadores no Rio de Janeiro da belle époque, Campinas, Editora da Unicamp, 2001.

CHAMBERS, Sarah C., "Crime and Citizenship: Judicial Practices in Arequipa, Peru, during the Transition from Colony to Republic", in Reconstructing Criminality in Latin America, eds. Carlos A. Aguirre and Robert Buffington, Wilmington, DE, Scholarly Resources, 2000, pp. 19-39.

CHOAIRY, Chafic, De "Turcos" a "Mascates": O questionamento da identidade sírio e libanese em Piracicaba (1889-1930), Tese de mestrado, São Carlos, Universidade Federal de São Carlos, 2013.

CORTÊS, Geraldo de Menezes, Migração e colonização no Brasil, Rio de Janeiro, Livraria J. Olympio Editôra, 1958.

COSTA, Maria Izabel Plath da, "Aspectos de textualidade em termos de declaração de inquéritos policiais”, Cadernos do IL, 38 (Jun. 2009), pp. 98-107.

CUNHA, Manoela Carneiro da, Negros estrangeiros: os escravos libertos e sua volta à África, São Paulo, Brasiliense, 1995.

DÁVILA, Jerry, Diploma of Whiteness: Race and Social Policy in Brazil, 1917-1945, Durham, Duke University Press, 2003.

DÁVILA, Jerry, “Ethnicity, identity and nationality in Latin America”, Jewish History 18 (2004), pp. 95-113. 
DERRIDA, Jacques, Of Grammatology, trans. Gayatri Chakravorty Spivak, Baltimore, Johns Hopkins University Press, 1997.

DOMINGUES, Petrônio, Uma história não contada: negro, racismo e branqueamento em São Paulo, São Paulo, SENAC, 2004.

FARFÁN-SANTOS, Elizabeth, Black Bodies, Black Rights: The Politics of Quilombismo in contemporary Brazil, Austin, University of Texas Press, 2016.

FARHAT, Emil, Dinheiro na estrada, São Paulo, T. A. Queiroz Editor, 1987.

FAUSTO, Boris, Crime e cotidiano: a criminalidade em São Paulo 1880-1924, São Paulo, EDUSP, 2001.

FAWAZ, Leila Tarazi, Occasion for War: Civil Conflict in Lebanon and Damascus in 1860, Berkeley, University of California Press, 1994.

GOULART, José A., O Mascate no Brasil, Rio de Janeiro, Conquista, 1967.

HOLLOWAY, Thomas H., Immigrants on the Land: Coffee and Society in São Paulo, 1886-1934, Chapel Hill, University of North Carolina Press, 1988.

HUTTER, Lucy M., Imigração italiana em São Paulo de 1902 a 1914: o processo imigratório, São Paulo, Instituto de Estudos Brasileiros, 1986.

KARPAT, Kemal H., "The Ottoman Emigration to America, 1860-1914," International Journal of Middle Eastern Studies 17.2 (1985), pp. 175-209.

KLICH, Ignacio, “Árabes, judíos y árabes judíos en la Argentina de la primera mitad de los novecientos”, Estudios Interdisciplinarios de América Latina y el Caribe, 6.2 (1995), pp. 109-143.

LESSER, Jeffrey, Immigration, Ethnicity, and National Identity in Brazil, 1808 to the Present, New York, Cambridge University Press, 2013.

LESSER, Jeffrey, Negotiating National Identity: Immigrants, Minorities, and the Struggle for Ethnicity in Brazil, Durham, Duke University Press, 1999.

LIPSITZ, George, The Possessive Investment of Whiteness: How White People Profit from Identity Politics, Philadelphia, Temple University Press, 2006.

LUJAN MUÑOZ, Jorge, "La literatura notarial en España e Hispanoamérica, 1500-1820", Anuario de Estudios Americanos, 38 (1981), pp. 101-116.

NISHIDA, Mieko, Slavery and Identity: Ethnicity, Gender, and Race in Salvador, Brazil, 1808-1888, Bloomington, Indiana University Press, 2003.

NUNES, Heliane Prudente, “Historiografia da imigração árabe nos Estados Unidos e no Brasil: uma perspectiva comparativa”, Textos de História 4.1 (1996), pp. 149-180.

O Debate (Sexta-feira, 4 de março de 1898), p. 2.

REYNA, V., TITCOMB, A., "Constraints on the suggestibility of Eyewitness Theory: A Fuzzy -Trace Theory Analysis", in Intersections in Basic and Applied Memory Research, eds. David G. Payne and Frederick G. Conrad, Mahwah, Lawrance Erlbaum Associates, 1997, pp. 157-174.

ROEDIGER, David R., The Wages of Whiteness: Race and the Making of the American Working Class, New York, Verso, 1991.

RODRIGUES, Raimundo Nina, As raças humanas e a responsabilidade penal no Brasil, $3^{\mathrm{a}}$ edição, Bahia, Progresso, 1957.

SALVATORE, Ricardo D., "Penitentiaries, Visions of Class, and Export Economies: Brazil and Argentina Compared," in The Birth of the Penitentiary in Latin America: Essays on Criminology, Prison 
Reform, and Social Control 1830-1940, eds. Ricardo D. Salvatore and Carlos Aguirre, Austin, University of Texas Press, 1996.

TAMARI, Salim, “Jerusalem's Ottoman Modernity: The Times and Lives of Wasif Jawhariyyeh", Jerusalem Quarterly File, 9 (Summer 2000), pp. 5-27.

TRUZZI, Oswaldo, "Religiosidade Cristã entre Árabes em São Paulo: Desafio no Passado e no Presente", Religião e Sociedade 36-2 (2016), pp. 266-291.

TRUZZI, Oswaldo, Sírios e libaneses: narrativas de história e cultura, São Paulo, Companhia Editora Nacional, 2005.

TURNER, Victor M., The Ritual Process: Structure and Anti-Structure, New Brunswick, Aldine Transaction, 1969.

\section{NOTES}

1. Archivo do Estado de São Paulo, Acervo Permanente-Processos Policiais (AESP,AP,PP), Jorge Cure, Antonio Bachera, 1.

2. AESP, AC, PP, box (bx.) C03234, Cure, Bachera, 2.

3. Idem.

4. Idem.

5. My emphasis. Idem, 3.

6. Idem, 6.

7. Idem, 9.

8. Idem.

9. Idem, 12.

10. Kemal H. Karpat, “The Ottoman Emigration to America, 1860 1914," International Journal of Middle Eastern Studies 17-2 (1985), pp. 175-176.

11. Oswaldo Truzzi, Sírios e libaneses: narrativas de história e cultura, São Paulo, Companhia Editora Nacional, 2005, pp. 41-42.

12. Sidney Chalhoub, Trabalho, lar e botequim: o cotidiano dos trabalhadores no Rio de Janeiro da belle époque, Campinas, Editora da Unicamp, 2001, p. 139; Jeffrey Lesser, Negotiating National Identity: Immigrants, Minorities, and the Struggle for Ethnicity in Brazil, Durham, Duke University Press, 1999, pp. 3-6; George Reid Andrews, Blacks and Whites in São Paulo 1888-1988, Madison, University of Wisconsin Press, 1991.

13. For the role of the peddler see, Heliane Prudente Nunes, "Historiographia da imigração árabe nos Estados Unidos e no Brasil: uma perspectiva comparativa”, Textos de História 4-1 (1996), pp. 149-180. For the term turco, see Chafic Choairy, "De "Turcos" a "Mascates": O questionamento da identidade sírio e libanese em Piracicaba (1889-1930)", Master Thesis, São Carlos, Universidade Federal de São Carlos, 2013, p. 42.

14. Boris Fausto, Crime e cotidiano: a criminalidade em São Paulo 1880-1924, São Paulo, EDUSP, 2001, p. 19.

15. Ricardo D. Salvatore, "Penitentiaries, Visions of Class, and Export Economies: Brazil and Argentina Compared," in The Birth of the Penitentiary in Latin America: Essays on Criminology, Prison Reform, and Social Control 1830-1940, eds. Ricardo D. Salvatore and Carlos Aguirre, Austin, University of Texas Press, 1996, p. 201. For a comparative essay see, Sarah C. Chambers, "Crime and Citizenship: Judicial Practices in Arequipa, Peru, during the Transition from Colony to Republic", in Reconstructing Criminality in Latin America, eds. Carlos A. Aguirre and Robert Buffington, Wilmington, DE, Scholarly Resources, 2000, pp. 19-39. 
16. Jerry Dávila, Diploma of Whiteness: Race and Social Policy in Brazil, 1917-1945, Durham, Duke University Press, 2003, p. 6.

17. See for example, David R. Roediger, The Wages of Whiteness: Race and the Making of the American Working Class, New York, Verso, 1991, and George Lipsitz, The Possessive Investment of Whiteness: How White People Profit from Identity Politics, Philadelphia, Temple University Press, 2006.

18. For an overview of immigration to Brazil, see Jeffrey Lesser, Immigration, Ethnicity, and National Identity in Brazil, 1808 to the Present, New York, Cambridge University Press, 2013; for the case of São Paulo, see Thomas H. Holloway, Immigrants on the Land: Coffee and Society in São Paulo, 1886-1934, Chapel Hill, University of North Carolina Press, 1988.

19. Pan American Union, "Brazil: New Naturalization Law", Bulletin of the Pan American Union 14 (1903), p. 386.

20. Kemal H. Karpat, “The Ottoman Emigration to America, 1860-1914”, International Journal of Middle East Studies 17-2 (1985), pp. 175-209; Leila Tarazi Fawaz, Occasion for War: Civil Conflict in Lebanon and Damascus in 1860, Berkeley, University of California Press, 1994, chapter 3.

21. Oswaldo Truzzi, "Religiosidade Cristã entre Árabes em São Paulo: Desafio no Passado e no Presente", Religião e Sociedade 36-2 (2016), pp. 267-268.

22. O Debate, Friday, March 4, 1898, p. 2.

23. Idem.

24. For the history of parochial tensions among these immigrants see, L. Fawaz, Occasion for War ..., pp. 9-11.

25. Jerry Dávila, "Ethnicity, identity and nationality in Latin America”, Jewish History 18 (2004), p. 111.

26. $O$ Debate, Friday, March 4, 1898, p. 2.

27. S. Chalhoub, Trabalho, lar e botequim..., p. 132.

28. Maria Aparecida Silva Bento, "Branqueamento e branquitude no Brasil", in Psicologia social do racismo - estudos sobre branquitude e branqueamento no Brasil, orgs. Iray Carone and Maria Aparecida Silva Bento, Petrópolis, RJ, Editora Vozes, 2002, pp. 25-58; J. Dávila, “Ethnicity, identity ...", p. 111.

29. Ignacio Klich, "Árabes, judíos y árabes judíos en la Argentina de la primera mitad de los novecientos", Estudios Interdisciplinarios de América Latina y el Caribe 6-2, available online at http:// www7.tau.ac.il/ojs/index.php/eial/article/view/1196/1224.

30. Salim Tamari, “Jerusalem's Ottoman Modernity: The Times and Lives of Wasif Jawhariyyeh", Jerusalem Quarterly File (Summer 2000), p. 12.

31. Renata Geraissati Castro de Almeida, "Trajetória de um patrício - A imigração sírio libanesa em São Paulo", Revista Outras Fronteiras 1-2 (2014), p. 303.

32. R. Almeida, “Trajetória de um patrício ...”, p. 323.

33. O. Truzzi, "Religiosidade Cristã ...", p. 629.

34. S. Chalhoub, Trabalho, lar e botequim ..., p. 26.

35. S. Chalhoub, Trabalho, lar e botequim ..., p. 123.

36. See, Peter Becker and Richard F. Wetzell, eds., Criminals and their Scientists, Cambridge, Cambridge University Press, 2006, and Carlos Aguirre and Robert Buffington, eds., Reconstructing Criminality in Latin America, Wilmington, DE, Scholarly Resources, 2000.

37. Petrônio Domingues, Uma história não contada: negro, racismo e branqueamento em São Paulo, São Paulo, SENAC, 2004, p. 365. European immigration to Brazil, see Lucy M. Hutter, Imigração italiana em São Paulo de 1902 a 1914: o processo imigratório, São Paulo, Instituto de Estudos Brasileiros, 1986; Geraldo de Menezes Cortês, Migração e colonização no Brasil, Rio de Janeiro, Livraria J. Olympio Editôra, 1958.

38. B. Fausto, Crime e cotidiano ..., p. 139

39. Elizabeth Farfán-Santos, Black Bodies, Black Rights: The Politics of Quilombismo in contemporary Brazil, Austin, University of Texas Press, 2016, pp. 51-52. 
40. Raimundo Nina Rodrigues, As raças humanas e a responsabilidade penal no Brasil, $3^{\text {rd }}$ edition, Bahia, Progresso, 1957, p. 79.

41. This is the only instance where Ottoman immigrants, or Arabs as indicated here, are compared to other sectors of Paulista society throughout Fausto's study.

42. I suspect that most of these individuals classified as Turkish were actually Sephardic Jews, since they have traditional Sephardic surnames. AESP, Justicia Policia (JP), E01616, n. 563, Alexander Gabriel Lafeicher; n. 612, Pedro Nahme; n. 527, Jose Abrão Cater.

43. Syrian: AESP, JP, E01616, n. 3 (7/8/1897), n. 6(7/18/1897), n. 12 (7/27/1897), n. 16 (8/3/1897), n. 34 (9/3/1897), n. 35 (9/5/1897), n. 37 (9/8/1897), n. 45 (9/11/1897), n. $46(9 / 12 / 1897)$, n. 94 (11/5/1897), n. 99 (11/13/1897), n. 114 (12/5/1897), n. 115 (12/5/1897), n. 120 (12/16/1897), n. 121 (12/15/1897), n. 122 (12/19/1897), n. $129(12 / 30 / 1897)$, n. $162(1 / 8 / 1898)$, n. 252 (6/2/1898), n. 258 (6/8/1898), n. 262 (6/13/1898), n. 263 (10/21/1898), n. 268-A (6/26/1898), n. $269(6 / 26 / 1898)$, n. 298 (8/1/1898), n. 353 (9/26/1898), n. 358 (7/15/1898), n. 359 (10/12/1898), n. 385 (11/21/1898), n. 407 (12/12/1898), n. 408 (12/19/1898), n. 415 (12/29/1898), n. 453 (2/17/1899), n. $462(2 / 26 / 1899)$, n. $470(3 / 5 / 1899)$, n. $483(3 / 10 / 1898)$, n. $522(4 / 22 / 1899)$, n. $528(4 / 28 / 1899)$, n. $537(4 / 28 / 1899)$, n. 563 (5/10/1899), n. 564 (5/10/1899), n. 612 (7/6/1899), n. 635 (7/23/1899), n. 670 (9/30/1899), n. 695 (S/D). Greek: AESP/JP, E01616, n. 127 (12/23/1897). The label Greek could either refer to the religion of the individual or the place of birth of the individual.

44. AESP, JP, E01616, n. 16 (8/3/1897).

45. AESP, JP, E01616, n. 46 (9/12/1897).

46. AESP, JP, E01616, n. 94 (11/5/1897).

47. AESP, JP, E01616, n. 262 (6/13/1898), n. 263 (10/21/1898).

48. Kathryn Burns, "Notaries, Truth, and Consequences", American Historical Review 110-2 (2005), p. 352. On the Iberian manuals used to shape notarial truth on both sides of the Atlantic, see Jorge Lujan Muñoz, "La literatura notarial en España e Hispanoamérica, 1500-1820", Anuario de Estudios Americanos 38 (1981), pp. 101-116.

49. K. Burns, "Notaries, Truth ...", p. 352.

50. K. Burns, "Notaries, Truth ...", p. 352.

51. AESP, AC, PP, bx. C03236, Merad-Najar, 1899, 1.

52. Idem.

53. Idem, 8.

54. Idem, 4-8.

55. Robert de Beaugrande and Wolfgang U. Dressler, Introduction to Text Linguistics, London, Longman, 1981; Gillian Brown, "Understanding Spoken Language", TOSOL Quarterly 12-3 (Sep. 1978), pp. 271-283; Maria Izabel Plath da Costa, "Aspectos de textualidade em termos de declaração de inquéritos policiais", Cadernos do IL 38 (Jun. 2009), pp. 98-107. For a theoretical and philosophical approach, see Jacques Derrida, Of Grammatology, trans. Gayatri Chakravorty Spivak, Baltimore, Johns Hopkins University Press, 1997.

56. AESP, AC, PP, bx. C03232, Antonio-Caram-Khamil, 1898, 15-22.

57. M. Costa, “Aspectos de textualidade ...", p. 101.

58. By liminal space, I am referring to the break between speech and written language where police scribes negotiate the multiple tasks needed to produce police documents such as depositions, reports, etc. For an explanation of liminal space or liminality, see Victor M. Turner, The Ritual Process: Structure and Anti-Structure, New Brunswick, Aldine Transaction, 1969, pp. 94-165.

59. K. Burns, "Notaries, Truth ...", p. 354.

60. According to Kathryn Burns, this is a different way of working with notarial records as discussed by James Lockhart in "Between the Lines", in Of Things of the Indies: Essays Old and New in Early Latin American History, Stanford, Stanford University Press, 1999, pp. 229-80. She states that "Lockhart does not draw on period legal literature, which can provide crucial context on the 
making and manipulation of documents, and he filters out textual formulae and odd inconsistencies (e.g., blank pages with signatures, doodles, practice signatures) that can be taken as invitations to ask how scribes co-produced the record, along with their clients, copyists, draftbooks, inkpots, and inside knowledge of legal ventriloquy. See Carolyn Dean, "Beyond the Notarial Template unpublished manuscript". See footnote 23 in K. Burns, "Notaries, Truth ...", p. 335.

61. AESP, AC, PP, bx. C03234, Busca Esia Aubud, 1898, 2.

62. Idem.

63. Idem

64. S. Chalhoub, Trabalho, lar e botequim ..., p. 81.

65. AESP, AC, PP, bx. C03234, Busca Esia Aubud, 1898, 4-5.

66. Idem, 5-6.

67. Idem, 6-7.

68. This phrase meaning 'in answer to the customary question' was part of the standardization of police proceedings because it established the eligibility of the witness, who in the official opinion of the authorities had not stated any disqualifiable statements to render the witness unlawful.

69. O. Truzzi, Sírios e libaneses ..., p. 333.

70. Mieko Nishida, Slavery and Identity: Ethnicity, Gender, and Race in Salvador, Brazil, 1808-1888, Bloomington, Indiana University Press, 2003, p. 20; Manoela Carneiro da Cunha, Negros estrangeiros: os escravos libertos e sua volta à África, São Paulo, Brasiliense, 1995, p. 32. For a brief history of the peddler in Brazil see José A. Goulart, o Mascate no Brasil, Rio de Janeiro, Conquista, 1967.

71. V. Reyna and A. Titcomb, "Constraints on the suggestibility of Eyewitness Theory: A Fuzzy Trace Theory Analysis", in Intersections in Basic and Applied Memory Research, eds. David G. Payne and Frederick G. Conrad, Mahwah, Lawrance Erlbaum Associates, 1997, p. 38.

72. V. Reyna and A. Titcomb, "Constraints on the suggestibility ...", p. 38.

73. V. Reyna and A. Titcomb, “Constraints on the suggestibility ...”, p. 160.

74. S. Chalhoul, Trabalho, lar e botequim ..., p. 131.

75. AESP, AC, PP, bx. C03234, Busca Eisa Aubud, 1898, 11.

76. Idem, 11-12.

77. Idem, 12.

78. Idem, 15.

79. Idem, 16.

80. Oswaldo Truzzi suggests that conflicts among Syrian-Lebanese were settled by the community members themselves. See O. Truzzi, Sírios e Libaneses ..., p. 40.

81. O. Truzzi, Sírios e Libaneses ..., pp. 40-41.

82. O. Truzzi, Sírios e Libaneses ..., pp. 40-41.

83. O. Truzzi, Sírios e Libaneses ..., p. 48.

84. See for example Emil Farhat, Dinheiro na estrada, São Paulo, T. A. Queiroz Editor, 1987.

\section{ABSTRACTS}

This article looks at intracommunal conflict among Ottoman immigrants in São Paulo, Brazil, at the end of the 1800s. It examines how community members sought the intervention of the 
positivist state as an additional strategy to resolve conflicts. It illustrates the ways notions of White Brazilian citizenship shaped intracommunal conflicts, specifically in the realm of business transactions and job opportunities. In the absence of traditional labor relations among Ottoman peddlers and or elite Ottoman businessmen, the latter surfaced as agents of community discipline to promote good work ethics and citizenship. Finally, it provides a glimpse into the reformed positivist police's inquisitorial logic of the and how it supported the racialization of commercial crimes.

Este artigo analisa os conflitos intracomunitários entre os imigrantes otomanos em São Paulo, Brasil, no final do século XIX. Explora como os membros da comunidade buscaram a intervenção do estado positivista como uma estratégia adicional para resolver conflitos. Ilustra as maneiras pelas quais as noções de uma cidadania branca brasileira moldam os conflitos intracomunitários, especificamente no campo das transações comerciais e da oportunidades de emprego. Na ausência de relações laborais tradicionais entre vendedores ambulantes e/ou a elite de empresários otomanos, estes surgiram como agentes de uma disciplina comunitária para promover a boa ética do trabalho e da cidadania. Finalmente, o artigo proporciona um vislumbre da reformada lógica inquisidora da polícia e como ela sustentou a racialização de crimes comerciais.

\section{INDEX}

Keywords: citizenship, positivism, whiteness, crimes, policing, immigration

Palavras-chave: cidadania, positivismo, brancura, crimes, policiamento, imigração

\section{AUTHOR}

JOSÉ D. NAJAR

Southern Illinois University

jnajar[at]siu.edu 